\title{
Hair Mineral Levels in Dogs with Atopic Dermatitis
}

\author{
Emanuela BADEA ${ }^{1 *}$, Gheorghe Valentin GORAN ${ }^{1}$, Victor CRIVINEANU ${ }^{1}$ \\ ${ }^{1}$ UASVM of Bucharest, Faculty of Veterinary Medicine, 050097, 105 Splaiul Independentei, 5th district, \\ Bucharest, Romania, EU \\ *corresponding author: emanuela.badea@gmail.com
}

Bulletin UASVM Veterinary Medicine 73(2) / 2016,

Print ISSN 1843-5270; Electronic ISSN 1843-5378

DOI:10.15835/buasvmcn-vm: 12217

\begin{abstract}
Atopic dermatitis is a genetic allergic skin disease that can be triggered by various environmental factors. This research aimed to study the possible correlation between heavy metal and mineral concentration and presence of atopic dermatitis. Hair samples from dogs suffering from atopic dermatitis were analyzed and compared to samples from the control group via ICP-OES method. Cu was the only element significantly decreased $(p=0.01)$ in the study group. No statistical significance was found for heavy metals.
\end{abstract}

Keywords: atopic dermatitis, dogs, hair, heavy metals, minerals

\section{INTRODUCTION}

Atopic dermatitis is a genetically predisposed allergic disease, characterized by skin inflammation and pruritus. (Halliwell, 2006) Along with genetics, other factors can trigger the appearance of atopic dermatitis, such as dietary hypersensitivity (Saridomichelakis and Olivry, 2016), bacterial infections, excessive heat, and exposure to skin irritants. (Williams, 2005) Various studies have taken into consideration the influence of heavy metal contamination on atopic dermatitis. (Kim, 2015) Chronical internal exposure to $\mathrm{Ni}, \mathrm{Co}$, and $\mathrm{Cr}$ can determine allergic cutaneous reactions (Basko-Plluska et al., 2011), as does exposure to other metals, like $\mathrm{Cd}, \mathrm{Pb}, \mathrm{Cu}$ (Koller, 1980), and Hg. (Park and Kim, 2011)

\section{AIMS AND OBJECTIVES}

The study aimed to determine the possible correlation between heavy metal and mineral concentration and presence of atopic dermatitis.

\section{MATERIALS AND METHODS}

Research was conducted on a study group (SG), consisting of six common breed dogs with atopic dermatitis (three males and three females, three above three years of age and three below three years of age), and a control group (CG), consisting of six clinically healthy common breed dogs (two males and four females, three above three years of age and three below three years of age).

Heavy metal and mineral concentration was determined using the ICP-OES method.

\section{RESULTS AND DISCUSSION}

Heavy metal and mineral mean concentration, standard deviation, standard error, and $p$-value are shown in Tab.1. Fig. 1 shows the mean heavy metal and mineral levels in the study group and control group with standard deviation error bars. As, Cd, and $\mathrm{Hg}$ mean levels were higher in the study group, and $\mathrm{Ni}$ and $\mathrm{Pb}$ mean levels were higher in the control group, but with no statistical significance. $\mathrm{K}, \mathrm{Mg}, \mathrm{Mo}, \mathrm{Na}$, and $\mathrm{Zn}$ mean levels were increased in the study groups, and $\mathrm{Al}, \mathrm{Ca}, \mathrm{Co}$, and Fe mean level was higher in the control group, but with no statistical significance. However, $\mathrm{Cu}$ was significantly decreased ( $p=0.01)$ in the study group. 
Tab. 1. Heavy metal and mineral mean concentration, standard deviation, standard error, and $p$-value

\begin{tabular}{cccccccc}
\hline \multirow{2}{*}{ Element } & \multicolumn{2}{c}{ Mean (ppm) } & \multicolumn{2}{c}{ Standard deviation } & \multicolumn{2}{c}{ Standard error } & \\
\cline { 2 - 7 } & Study group & $\begin{array}{c}\text { Control } \\
\text { group }\end{array}$ & Study group & $\begin{array}{c}\text { Control } \\
\text { group }\end{array}$ & Study group & $\begin{array}{c}\text { Control } \\
\text { group }\end{array}$ & p-value \\
\hline $\mathrm{Al}$ & 129.24 & 138.85 & 52.88 & 65.72 & 26.44 & 13.22 & 0.9886 \\
\hline $\mathrm{As}$ & 1.08 & 1.04 & 0.23 & 0.23 & 0.10 & 0.05 & 0.3546 \\
\hline $\mathrm{Ca}$ & 2059.52 & 2705.74 & 1612.97 & 999.59 & 806.49 & 403.24 & 0.8319 \\
\hline $\mathrm{Cd}$ & 0.60 & 0.47 & 0.13 & 0.17 & 0.05 & 0.03 & 0.4764 \\
\hline $\mathrm{Co}^{*}$ & 5.93 & 7.30 & 2.50 & 3.44 & 1.02 & 0.51 & 0.5436 \\
\hline $\mathrm{Cu}$ & 6.18 & 18.83 & 3.56 & 1.23 & 1.78 & 0.89 & 0.0106 \\
\hline $\mathrm{Fe}$ & 129.70 & 179.76 & 69.49 & 86.31 & 34.74 & 17.37 & 0.6975 \\
\hline $\mathrm{Hg}$ & 0.48 & 0.39 & 0.15 & 0.14 & 0.06 & 0.03 & 0.4590 \\
\hline $\mathrm{K}$ & 1169.09 & 865.77 & 959.36 & 336.58 & 479.68 & 239.84 & 0.4050 \\
\hline $\mathrm{Mg}$ & 168.34 & 167.46 & 140.26 & 35.30 & 70.13 & 35.07 & 0.7016 \\
\hline $\mathrm{Mo}$ & 11.58 & 10.08 & 3.91 & 1.72 & 1.60 & 0.80 & 0.1808 \\
\hline $\mathrm{Na}$ & 1969.20 & 1379.62 & 933.27 & 667.53 & 466.63 & 329.96 & 0.4447 \\
\hline $\mathrm{Ni}$ & 1.24 & 1.98 & 0.78 & 0.12 & 0.35 & 0.17 & 0.1825 \\
\hline $\mathrm{Pb}$ & 1.32 & 1.81 & 0.83 & 0.93 & 0.34 & 0.17 & 0.5808 \\
\hline $\mathrm{Zn}$ & 148.50 & 138.24 & 10.45 & 24.30 & 5.22 & 2.61 & 0.3173 \\
\hline${ }^{*}$ mean concentration measured in ppb & & & & & &
\end{tabular}

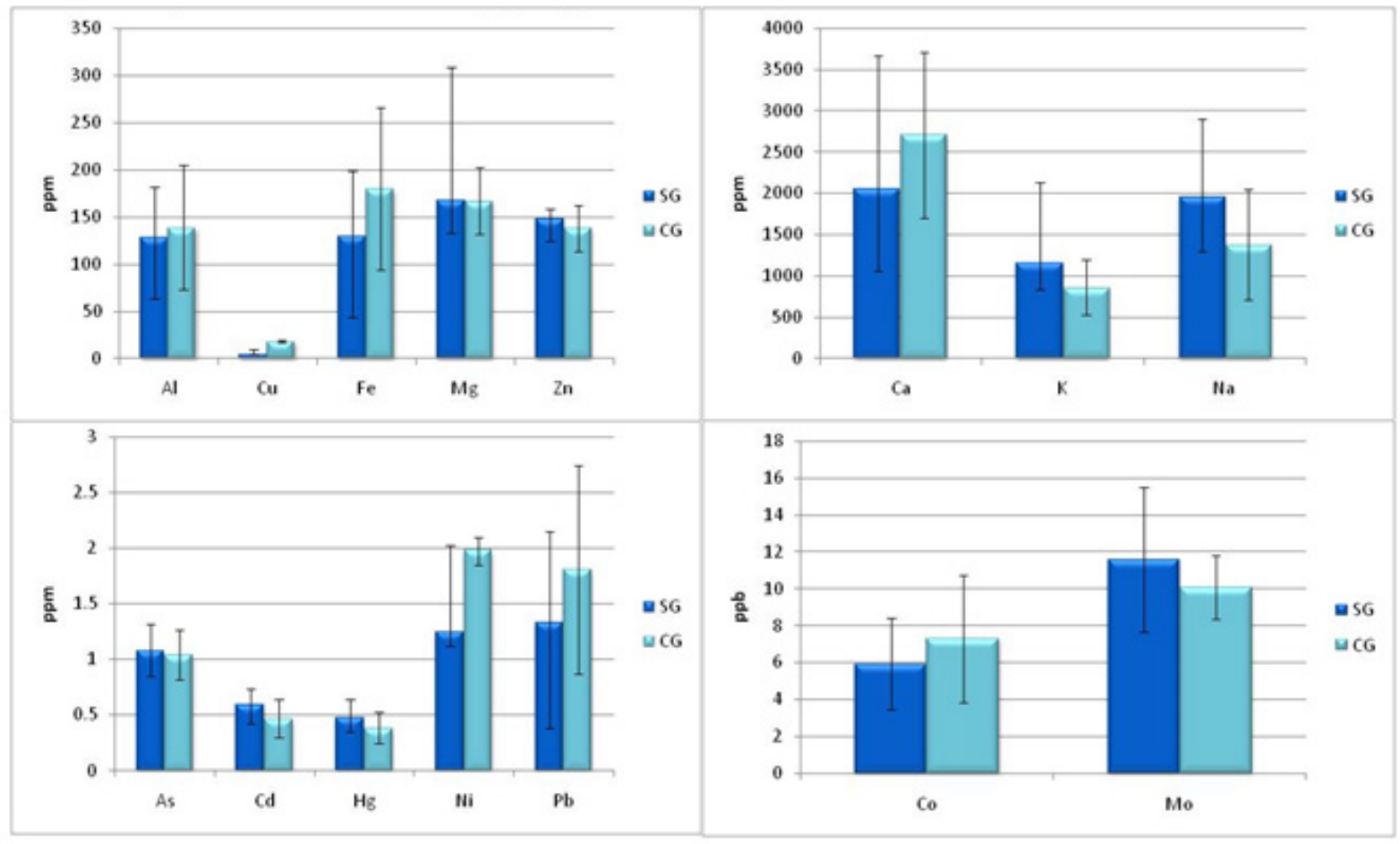

Fig.1. Mean heavy metal and mineral levels in the SG and CG

\section{CONCLUSION}

No statistical significance has been registered for heavy metals and minerals present in hair samples from dogs with atopic dermatitis, excepting $\mathrm{Cu}$, which was significantly decreased $(p$ $=0.01$ ) in the study group, implying a Cu deficiency in atopic dermatitis. In samples from the study group, As, Cd, and Hg registered higher levels. 


\section{REFERENCES}

1. Basko-Plluska JL, Thyssen JP, Schalock PC (2011). Cutaneous and systemic hypersensitivity reactions to metallic implants. Dermatitis 22(2):65-79.

2. Halliwell R (2006). Revised nomenclature for veterinary allergy. Vet Immunol Immunopathol 114(3-4):207-208.

3. Kim K (2015). Influences of Environmental Chemicals on Atopic Dermatitis. Toxicol Res 31(2):89-96.

4. Koller LD (1980). Immunotoxicology of heavy metals. Int J Immunopharmacol 2(4):269-79.
5. Park H, Kim K (2011t). Association of blood mercury concentrations with atopic dermatitis in adults: a population-based study in Korea. Environ Res 111(4):5738.

6. Saridomichelakis MN, Olivry T (2016). An update on the treatment of canine atopic dermatitis. Vet J 207:29-37.

7. Williams HC (2005). Atopic dermatitis. N Engl J Med 352(22):2314-24. 